\title{
T2D Risk Haplotypes of the TCF7L2 Gene in the Czech Population Sample: the Association With Free Fatty Acids Composition
}

\author{
J. VČELÁK ${ }^{1}$, D. VEJRAŽKOVÁ ${ }^{1}$, M. VAŇKOVÁ ${ }^{1}$, P. LUKÁŠOVÁ ${ }^{1}$, O. BRADNOVÁ ${ }^{1}$, \\ T. HÁLKOVÁ ${ }^{1}$, J. BEŠŤ́́K ${ }^{1}$, K. ANDĚLOVÁ ${ }^{2}$, H. KVASNIČKOVÁ ${ }^{1}$, P. HOSKOVCOVÁ ${ }^{1}$, \\ K. VONDRA ${ }^{1}$, J. VRBÍKOVÁ ${ }^{1}$, B. BENDLOVÁ ${ }^{1}$ \\ ${ }^{1}$ Institute of Endocrinology, Prague, Czech Republic, ${ }^{2}$ Institute for the Care of Mother and Child, \\ Prague, Czech Republic
}

Received October 19, 2011

Accepted March 16, 2012

On-line April 5, 2012

\section{Summary}

The association of transcription factor 7-like 2 (TCF7L2) gene variants with the pathogenesis of T2D, gestational diabetes and polycystic ovary syndrome (PCOS) was examined. The study involved 1460 individuals: 347 T2D patients (D); 261 gestational diabetics (G); 147 offspring of T2D (O); 329 women with PCOS, and 376 controls (C). The SNPs: rs7901695; rs7903146; rs12255372 in the TCF7L2 gene were genotyped. Anthropometric and biochemical parameters, OGTT derived indices were assessed. In addition, free fatty acids (FFAs) were evaluated in 183 non-diabetic women. The CTT haplotype showed the strongest association with T2D with $O R$ 1.57, $p=0.0003$. The frequency of the CTT/CTT haplotype was decreasing in following order: D 10.6, O 9.5, G 6.1, C 5.3 and PCOS 4.9 [\%]. Among $\mathrm{CTT}$ carriers, significantly decreased levels of oGTT-stimulated insulin and C-peptide as well as proportions of fasting PUFAs were observed. The carriership of CTG/TCG was associated with gestational diabetes, OR 2.59, $p=0.036$. The association of TCF7L2 haplotypes with T2D and gestational diabetes but not with PCOS was confirmed. Novel association of TCF7L2 with FFAs composition was found.

\section{Key words}

TCF7L2 • Haplotypes • Type 2 diabetes • Gestational diabetes • Genetics • Polycystic ovary syndrome • Diabetes risk • Free fatty acids $\bullet$ Polyunsaturated fatty acids

\section{Corresponding author}

J. Vcelak, Department of Molecular Endocrinology, Institute of Endocrinology, Narodni 8, 11694 Prague 1, Czech Republic. Fax: +420 224905 325. E-mail: jvcelak@endo.cz

\section{Introduction}

Common variants in the transcription factor 7like 2 (TCF7L2) gene have been identified as the strongest genetic risk factors for type 2 diabetes (T2D) in multiple ethnic groups (Cauchi et al. 2006, De Silva et al. 2007, Tong et al. 2009, Ereqat et al. 2010, Palmer et al. 2010, Lin et al. 2010, Cruz et al. 2010, Wen et al. 2010, Gambino et al. 2010, Chauhan et al. 2010). At the individual level, the TCF7L2 risk allele carriership increases $\mathrm{T} 2 \mathrm{D}$ risk for $50 \%$, the population attributable risk varies between 10-25\% depending on allele frequency (Zeggini and McCarthy 2007, Cauchi and Froguel 2008, Yan et al. 2009). Common variants in TCF7L2 also predicted future T2D among persons with impaired glucose tolerance (Florez et al. 2006, Lyssenko et al. 2007). However, the mechanisms by which these non-coding variants increase risk of $\mathrm{T} 2 \mathrm{D}$ have been unknown so far.

TCF7L2 is expressed in most human tissues, including pancreatic beta cells, liver, omental as well as subcutaneous adipose tissue, and brain. Low is the expression in human skeletal muscle. Its expression was significantly decreased in subcutaneous and omental fat from obese T2D patients in comparison with obese normoglycemic subjects (Cauchi et al. 2006). On the other hand, the mRNA level of TCF7L2 was 5-fold higher in pancreatic islets from T2D patients than normoglycemic donors. In human islets, TCF7L2 expression associated positively with insulin gene expression but negatively with glucose-stimulated insulin 
Table 1. Study subjects.

\begin{tabular}{|c|c|c|c|}
\hline & $\mathbf{n}$ & Age (years \pm SD) & BMI $\left(\mathrm{kg} / \mathrm{m}^{2} \pm \mathrm{SD}\right)$ \\
\hline T2D patients & 347 & & \\
\hline females & 232 & $58.0 \pm 9.9$ & $31.8 \pm 5.6$ \\
\hline males & 115 & $61.4 \pm 7.4$ & $29.7 \pm 4.7$ \\
\hline PCOS & 329 & $27.5 \pm 6.3$ & $27.0 \pm 6.6$ \\
\hline Gestational diabetics & 261 & $32.8 \pm 4.9$ & $23.8 \pm 4.1$ \\
\hline Offspring of $T 2 D$ & 147 & & \\
\hline females & 99 & $37.2 \pm 12.8$ & $25.1 \pm 4.4$ \\
\hline males & 48 & $39.3 \pm 10.1$ & $26.7 \pm 4.5$ \\
\hline Controls & 376 & & \\
\hline females & 253 & $29.9 \pm 10.8$ & $23.3 \pm 4.4$ \\
\hline males & 123 & $29.4 \pm 7.8$ & $24.0 \pm 2.9$ \\
\hline Total & 1460 & & \\
\hline
\end{tabular}

release suggesting posttranscriptional defect in insulin secretion (Lyssenko et al. 2007). Recently, the tissuespecific alternative splicing of TCF $\angle 2$ was identified and the expression of splicing forms was influenced by intronic variants of the gene (Osmark et al. 2009).

$T C F 7 L 2$ is a transcription factor involved in the Wnt signaling pathway which plays a crucial role in cell proliferation, differentiation and apoptosis, in the maintenance of tissue homeostasis, and probably in metabolic processes (Smith et al. 2007). The impairment of Wnt signaling is associated with many disorders ranging from cancer to the degenerative disorders such as Alzheimer disease. First evidence about the importance of Wnt signaling for pancreatic organogenesis was given by Papandopoulou and Edlund (2007) but there are discrepant data on the role of Wnt signaling in mature islets. Wnt signaling was found to be activated in T2D patients in comparison to normoglycemic donors. In nondiabetic mice model, high fat diet induced Wnt activation (Lee et al. 2008). The authors suggest the exaggerated activation as an adaptive mechanism promoting beta-cell proliferation in early T2D but, in contrast, chronic pathway activation as a process leading to cell death. In addition, Wnt signaling seems to be both an inducer and effector of glucagon-like peptide-1 (GLP-1) (Gustafson and Smith 2008).

Most recently, two publications (Pearson 2009, Villareal et al. 2010) reviewed the possible mechanisms explaining how altered TCF7L2 production or function may cause diabetes. Among them, reduced insulinotropic effect of incretin hormones (esp. GLP-1 signaling in beta cells), the impaired insulin processing or release, and decreased beta cell mass seem to be the most probable etiological mechanisms.

The aim of our study was to examine the possible impact of the three TCF7L2 single nucleotide polymorphisms (SNPs) on the pathogenesis of T2D, gestational diabetes, and polycystic ovary syndrom (PCOS) in the Czech population representatives and to ascertain the influence of $\mathrm{T} 2 \mathrm{D}$-associated variants on hormonal and other clinical characteristics.

\section{Methods}

\section{Study subjects}

1460 adult subjects aged 18-70 years meeting the following criteria of the selection entered the study: 347 patients suffering from type 2 diabetes mellitus diagnosed by the criteria of the World Health Organization (World Health Organization Expert Committee 1999); 261 gestational diabetics meeting the 0.5-1 year interval after childbirth without other pathologies (i.e. hormonal disturbances, infections, organ disorders, mental illness etc.); 329 patients with PCOS defined according to the European Society of Human Reproduction and Embryology consensus (Rotterdam ESHRE/ASRM-Sponsored PCOS Consensus Workshop Group 2004), none of them was taking hormonal contraception at least three months before the day of the examination; 147 offspring of T2D patients (T2D was 
present in one or both parents) without other pathologies, and 376 healthy controls without family history of T2D, PCOS, and gestational diabetes. The study cohorts are characterized in Table 1. All the T2D patients were well compensated either only by diet $(41.6 \%)$, or by diet and peroral antidiabetic drugs $(39.8 \%)$, and/or by insulin (18.6\%). Except of the diabetics, most subjects have normal glucose tolerance, only 8 gestational diabetics, 7 offspring, 21 PCOS, and 10 controls were additionally found to have impaired glucose tolerance (i.e. glucose in $120 \mathrm{~min}$ of oGTT $\geq 7.8$ and $<11.0 \mathrm{mmol} / \mathrm{l}$ ), none of them had T2D.

The study protocol was in accordance with the institutional ethic guidelines and the national rules and all the subjects gave their written informed consent to participate in the study.

\section{Clinical and biochemical characterization}

Body weight, height, waist and hip circumferences were measured in all participants in order to calculate body mass index (BMI) and to evaluate body fat distribution by means of waist circumference and waist to hip ratio (WHR). Furthermore, 14 skinfolds were measured and body composition (\% of subcutaneous fat mass, $\%$ of muscle mass, and \% of bone mass) was then calculated using the ANTROPO program (Blaha 1991).

Venous blood samples were obtained after an overnight fast. Glucose metabolism was characterized by blood glucose (Beckman Glucose Analyser 2), immunoreactive insulin (IRI; Immunotech IRMA, Czech Rep), C-peptide (Immunotech IRMA, Czech Rep), proinsulin (DRG Diagnostics, Germany), and also by glucagon (IBL-International, Germany).

The 3-hour oral glucose tolerance test (oGTT) with $75 \mathrm{~g}$ of glucose load was performed in all subjects except of T2D patients. Areas under the oGTT glycemic, C-peptide and insulin curves (AUC) were calculated. Lipid profile was assessed by total cholesterol $(\mathrm{CH})$, HDL-CH, LDL-CH and triglycerides (TG) concentrations (analyzer Integra 400+, Roche Diagnostics $\mathrm{GmbH}$, Germany). To assess insulin sensitivity and beta-cell function, the homeostasis models assessment HOMA R $=\left(\mathrm{I}_{0} * \mathrm{G}_{0} / 22.5\right)$ and HOMA $\mathrm{F}=20 * \mathrm{I}_{0} /\left(\mathrm{G}_{0}-3.5\right)$,

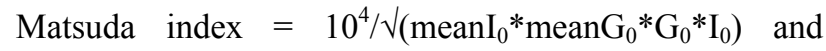
insulinogenic index $=\left(\mathrm{I}_{30}-\mathrm{I}_{0}\right) /\left(\mathrm{G}_{30}-\mathrm{G}_{0}\right)$ were used. Furthermore, products of insulin sensitivity and beta cell function, i.e. disposition indices were calculated. Basal free fatty acids (FFA0) concentrations and also oGTTinfluenced FFAs levels in $60^{\text {th }}\left(\right.$ FFA60) and $180^{\text {th }} \mathrm{min}$
(FFA180) were evaluated by NEFA C ACS-ACOD (Wako Chemicals GmbH, Germany). FFAs composition was assessed by gas chromatography (GC-14A instrument, Shimadzu, Kyoto, Japan) after the extraction and subsequent derivatization by isooctanemethylchloroformiate, 5:1. Heptadecanoic acid (C17:0) was used as internal standard (Husek et al. 2002). Saturated fatty acids (SFAs) fraction included C12:0, C14:0, C16:0, C18:0. Monounsaturated fatty acids (MUFAs) fraction consisted of C16:1n-7, C18:1n-7, C18:1n-9, C20:1n-9 and polyunsaturated fatty acids (PUFAs) fraction of C18:2n-6, C18:3n-3, C20:3n-6, C20:4n-6, C22:6n-3. The percentages of fatty acids subgroups (\%SFA, \%MUFA, \%PUFA) out of the total FFAs derived from GC method were evaluated.

\section{TCF7L2 genotyping and haplotype construction}

DNA extracted from peripheral leukocytes (QIAamp DNA Blood Kit, QIAGEN, Germany) was used to genotype for rs7901695 (T>C); rs7903146 (C>T); rs12255372 $(\mathrm{G}>\mathrm{T})$ intronic variants by $\mathrm{ABI}$ TaqMan SNP Genotyping Assays (LightCycler 480 System, Roche). The positive and negative controls were used in every run. The particular haplotypes and haplotype combinations were generated by PHASE version 2.1. software (Stephens and Donnelly 2003).

\section{Statistical analysis}

For the statistical evaluation, NCSS 2004 (Statistical Solutions, Saugus, USA) software was used. Data are given as means \pm SDs or percentages. The Chisquare test was used to assess deviation from HardyWeinberg equilibrium of the genotype frequencies. Analysis of linkage disequilibrium (LD) and correlation coefficient between the SNPs $\left(\mathrm{r}^{2}\right)$ was performed by Haploview 4.1. (Barrett et al. 2005). Allele/genotype/haplotype frequencies were compared by Chi-square test or Fisher's exact tests. Odds ratios (OR) and $95 \%$ Confidence Intervals (CI) according to Woolf formula were calculated. Differences in biochemical and anthropometric data between the compared groups were tested by non-parametric Mann-Whitney test. When appropriate, data were adjusted for age or for age and BMI or HOMA R using the GLM Anova. The p-values $<0.05$ (two tailed) were considered to be significant.

\section{Results}

The frequencies of rs7901695 (T>C); rs7903146 
Table 2. TCF7L2 gene polymorphisms rs7901695, rs7903146, rs12255372 - genotype, allele and haplotype frequencies in the Czech cohorts of T2D patients, gestational diabetics, offspring of T2D, patients with polycystic ovary syndrome and controls.

\begin{tabular}{|c|c|c|c|c|c|}
\hline & T2D patients & Offspring of T2D & Gestat. Diabetics & PCOS & Controls \\
\hline \multicolumn{6}{|l|}{$r s 7901695(T>C)$} \\
\hline$T T$ & $40.5 \%$ & $50.4 \%$ & $40.7 \%$ & $51.2 \%$ & $53.0 \%$ \\
\hline$T C$ & $46.4 \%$ & $37.8 \%$ & $49.8 \%$ & $41.0 \%$ & $40.1 \%$ \\
\hline$C C$ & $13.1 \%$ & $11.8 \%$ & $9.5 \%$ & $7.7 \%$ & $6.9 \%$ \\
\hline T carriership & $63.7 \%$ & $69.2 \%$ & $65.6 \%$ & $71.8 \%$ & $73.1 \%$ \\
\hline C carriership & $36.3 \%$ & $30.8 \%$ & $34.4 \%$ & $28.2 \%$ & $26.9 \%$ \\
\hline \multicolumn{6}{|l|}{$r s 7903146(C>T)$} \\
\hline$C C$ & $42.6 \%$ & $50.0 \%$ & $41.5 \%$ & $54.0 \%$ & $54.5 \%$ \\
\hline$C T$ & $44.9 \%$ & $39.2 \%$ & $49.2 \%$ & $38.6 \%$ & $39.0 \%$ \\
\hline$T T$ & $12.5 \%$ & $10.7 \%$ & $9.3 \%$ & $7.3 \%$ & $6.5 \%$ \\
\hline C carriership & $65.0 \%$ & $69.6 \%$ & $66.1 \%$ & $73.3 \%$ & $73.9 \%$ \\
\hline T carriership & $35.0 \%$ & $30.4 \%$ & $33.8 \%$ & $26.7 \%$ & $26.1 \%$ \\
\hline \multicolumn{6}{|l|}{$r s 12255372(G>T)$} \\
\hline$G G$ & $43.5 \%$ & $54.3 \%$ & $47.3 \%$ & $57.5 \%$ & $54.8 \%$ \\
\hline$G T$ & $43.8 \%$ & $35.0 \%$ & $44.1 \%$ & $36.4 \%$ & $39.0 \%$ \\
\hline$T T$ & $12.6 \%$ & $10.7 \%$ & $8.6 \%$ & $6.1 \%$ & $6.2 \%$ \\
\hline G carriership & $65.4 \%$ & $71.8 \%$ & $70.0 \%$ & $75.7 \%$ & $74.3 \%$ \\
\hline T carriership & $34.6 \%$ & $28.2 \%$ & $30.0 \%$ & $24.3 \%$ & $25.7 \%$ \\
\hline \multicolumn{6}{|c|}{ Haplotype combination } \\
\hline$T C G / T C G$ & $36.4 \%$ & $47.6 \%$ & $38.3 \%$ & $48.3 \%$ & $48.9 \%$ \\
\hline$C T T / T C G$ & $37.9 \%$ & $32.0 \%$ & $38.3 \%$ & $32.8 \%$ & $34.3 \%$ \\
\hline CTT/CTT & $10.7 \%$ & $9.5 \%$ & $6.1 \%$ & $4.9 \%$ & $5.3 \%$ \\
\hline TCG carriership & $65.1 \%$ & $71.4 \%$ & $69.4 \%$ & $75.3 \%$ & $74.6 \%$ \\
\hline CTT carriership & $34.9 \%$ & $28.6 \%$ & $30.6 \%$ & $24.7 \%$ & $25.4 \%$ \\
\hline
\end{tabular}

$(\mathrm{C}>\mathrm{T})$; rs12255372 $(\mathrm{G}>\mathrm{T})$ of TCF7L2 gene in our cohorts are given in Table 2. All the genotype distributions were in Hardy-Weinberg equilibrium. The frequency of the risk alleles of all variants decreased in the following order: T2D patients (D), offspring of T2D (O), gestational diabetics $(G)$, with the lowest number in PCOS patients (PCOS) and in controls (C). The genotype as well as allele distributions differed significantly between $\mathrm{D}$ and $\mathrm{C}$ in all tested polymorphisms (Chi-square test for genotype distribution: rs7901695, $\mathrm{p}=0.0008$; rs7903146, $\mathrm{p}=0.0012$; rs12255372, $\mathrm{p}=0.0013$; for allele distribution rs7901695, $\mathrm{p}<0.00001 ; \quad \mathrm{rs} 7903146$, $\mathrm{p}<0.00001 ; \mathrm{rs} 12255372, \mathrm{p}<0.00001)$ and between $\mathrm{G}$ and C (Chi-sqare test for genotype distribution: rs7901695, $\mathrm{p}=0.019$; rs7903146, $\mathrm{p}=0.02$; for allele distribution rs7901695, $\mathrm{p}=0.005$; rs7903146, $\mathrm{p}=0.003$; rs12255372, $\mathrm{p}=0.018)$

The carriership of these particular three risk variants was significantly associated with T2D. The ORs are given in Table 3. The $\mathrm{C}$ allele in rs7901695 and $\mathrm{T}$ allele in rs7903146 were also associated with an increased risk of gestational diabetes (Table 3).

The haplotype analysis was performed. The two polymorphisms rs7901695 and rs7903146 are in a strong linkage disequilibrium with correlation coefficient $r^{2}=0.98$ and thus build one haplotype block. The $r^{2}$ between the variants rs7903146 and rs12255372 is 0.91 . PHASE v.2.1.1. generated 8 haplotypes (TCG in $66 \%$, CTT in $26 \%$, CTG in $3 \%$, CCG in $2 \%$, TCT in $1.6 \%$ and TTT, CCT, TTG all in $<1 \%$ of subjects in our cohorts) and 13 haplotype combinations. Four most frequent haplotype combinations (TCG/TCG; CTT/TCG; 
Table 3. Odds ratios for rs7901695 (T>C), rs7903146 (C>T), rs12255372 (G>T) and haplotype combination in TCF7L2 gene in the Czech cohorts.

\begin{tabular}{|c|c|c|c|c|c|c|}
\hline \multirow{2}{*}{$r s 7901695(T>C)$} & \multicolumn{3}{|c|}{ Risk homozygotes CC vs. others } & \multicolumn{3}{|c|}{$\mathrm{C}$ allele carriers vs. $\mathrm{T}$ allele carriers } \\
\hline & OR* & {$[95 \% \mathrm{CI}]$} & $p$ (Yates) & OR & {$[95 \% \mathrm{CI}]$} & $p$ (Yates) \\
\hline T2D patients vs. Controls & 2.04 & {$[1.22-3.40]$} & 0.0085 & 1.55 & {$[1.23-1.94]$} & 0.0002 \\
\hline Offspring of T2D vs. Controls & 1.82 & {$[0.95-3.48]$} & 0.099 & 1.21 & [0.89-1.63] & 0.252 \\
\hline Gestational diabetics vs. Controls (females) & 1.60 & {$[0.82-3.13]$} & 0.224 & 1.44 & {$[1.10-1.89]$} & 0.0098 \\
\hline PCOS vs. Controls (females) & 0.73 & {$[0.34-1.55]$} & 0.501 & 1.08 & {$[0.83-1.41]$} & 0.595 \\
\hline \multirow{2}{*}{$r s 7903146(C>T)$} & \multicolumn{3}{|c|}{ Risk homozygotes TT vs. others } & \multicolumn{3}{|c|}{ T allele carriers vs. $C$ allele carriers } \\
\hline & OR* & {$[95 \% \mathrm{CI}]$} & $p$ (Yates) & OR & {$[95 \% \mathrm{CI}]$} & $p$ (Yates) \\
\hline T2D patients vs. Controls & 2.05 & {$[1.21-3.46]$} & 0.0092 & 1.52 & {$[1.22-1.92]$} & 0.0003 \\
\hline Offspring of T2D vs. Controls & 1.72 & {$[0.87-3.37]$} & 0.164 & 1.24 & {$[0.90-1.68]$} & 0.192 \\
\hline Gestational diabetics vs. Controls (females) & 1.33 & {$[0.70-2.51]$} & 0.476 & 1.41 & {$[1.08-1.84]$} & 0.0148 \\
\hline PCOS vs. Controls (females) & 1.02 & {$[0.54-1.96]$} & 0.920 & 1.01 & {$[0.76-1.31]$} & 0.951 \\
\hline \multirow{2}{*}{ rs $12255372(G>T)$} & \multicolumn{3}{|c|}{ Risk homozygotes TT vs. others } & \multicolumn{3}{|c|}{ T allele carriers vs. $C$ allele carriers } \\
\hline & $\mathbf{O R}^{*}$ & {$[95 \% \mathrm{CI}]$} & $p$ (Yates) & OR & {$[95 \%$ CI $]$} & p (Yates) \\
\hline T2D patients vs. Controls & 2.17 & [1.28-3.68] & 0.0054 & 1.52 & [1.21-1.91] & 0.0004 \\
\hline Offspring of T2D vs. Controls & 1.79 & {$[0.91-3.55]$} & 0.131 & 1.13 & {$[0.83-1.54]$} & 0.474 \\
\hline Gestational diabetics vs. Controls (females) & 1.26 & {$[0.65-2.44]$} & 0.621 & 1.25 & {$[0.95-1.65]$} & 0.129 \\
\hline PCOS vs. Controls (females) & 0.88 & {$[0.45-1.74]$} & 0.848 & 0.91 & {$[0.69-1.20]$} & 0.545 \\
\hline \multirow[t]{2}{*}{ Haplotype combination } & \multicolumn{3}{|c|}{$\begin{array}{l}\text { Risk homozygotes CTT/CTT vs. } \\
\text { TCG haplotype carriers }\end{array}$} & \multicolumn{3}{|c|}{$\begin{array}{l}\text { CTT haplotype carriers vs. } \\
\text { TCG haplotype carriers }\end{array}$} \\
\hline & $\mathbf{O R}^{*}$ & {$[95 \% \mathrm{CI}]$} & p (Yates) & OR & {$[95 \% \mathrm{CI}]$} & $p$ (Yates) \\
\hline T2D patients vs. Controls & 2.25 & {$[1.25-3.98]$} & 0.0065 & 1.57 & {$[1.23-2.01]$} & 0.0003 \\
\hline Offspring of T2D vs. Controls & 1.87 & {$[0.92-3.83]$} & 1.224 & 1.18 & {$[0.86-1.62]$} & 0.352 \\
\hline Gestational diabetics vs. Controls (females) & 1.11 & {$[0.54-2.31]$} & 0.921 & 1.26 & [0.94-1.69] & 0.142 \\
\hline PCOS vs. Controls (females) & 0.73 & {$[0.34-1.55]$} & 0.523 & 0.91 & {$[0.69-1.22]$} & 0.604 \\
\hline
\end{tabular}

* ORs for recessive model

CTT/CTT and CTG/TCG) were examined methodically with the following results: the frequency of the risk homozygous CTT/CTT haplotype combination was decreasing in the studied groups as follows: D $10.7 \%$, O $9.5 \%$, G $6.1 \%$, C $5.3 \%$ and PCOS $4.9 \%$ (Table 2). The distribution of CTT carriers did not differ within the particular groups with respect to the BMI categorization (BMI $<25 ; \geq 25$ and $<30 ; \geq 30 \mathrm{~kg} / \mathrm{m}^{2}$ - data not shown). The estimated OR of T2D for the CTT haplotype carriers was 1.57 [95\% CI 1.23-2.01], $\mathrm{p}=0.0003$; for CTT homozygotes the OR was 2.25 [1.25-3.98], $\mathrm{p}=0.006$ (Table 3). Interestingly, the frequency of the fourth most often haplotype combination CTG/TCG was almost twice higher in $\mathrm{G}$ compared with all the other studied groups ( $7.7 \%$ vs. $2.9 \%$ in C, $3.8 \%$ in D, $4.1 \%$ in O, and $4.3 \%$ in PCOS) resulting in the association of the CTG/TCG carriership with gestational diabetes (OR 2.59 [1.126.01], $\mathrm{p}=0.036$ - data not shown).

Relationship between the haplotype combinations and anthropometric as well as biochemical data was tested in our particular cohorts of $\mathrm{O}, \mathrm{G}, \mathrm{PCOS}$, and C. Analyzed separately, we did not observe the influence of the particular haplotypes on body weight, body composition, fasting and stimulated glucose, insulin, proinsulin, C-peptide and glucagon levels and on any other screened parameter. To increase the statistical 
power, we pooled together all the non-diabetic women $(n=942)$ for further analyses. After that, significantly decreased levels of oGTT-stimulated C-peptide and insulin in $30^{\text {th }}, 60^{\text {th }}$, and $90^{\text {th }}$ min as well as lower AUCs of these two hormones were apparent in CTT risk haplotype carriers when compared with non-risk TCG/TCG configuration (Fig. 1). However, proinsulin, glucagon, HOMA F, insulinogenic index, HOMA R, Matsuda index and disposition indices did not differ between the haplotypes (Fig. 2-3). Concerning our D group, majority of diabetics $(66 \%)$ was treated by derivatives of sulfonylurea and $18.6 \%$ were insulintreated. As it is well known that this treatment influences parameters of glucose as well as lipid metabolism and body composition (United Kingdom Prospective Diabetes Study Group 1998), we did not evaluate possible association of the risk genotype with these markers in diabetic patients.

As a pilot study, we tested the interaction between the TCF7L2 gene polymorphisms and FFAs composition in 183 non-diabetic women. Plasma levels of total fasting as well as 3-hour oGTT-influenced FFAs did not differ with respect to the haplotype. Interestingly, highly significant association of the risk haplotype CTT with decreased $\%$ of fasting PUFAs was observed $(\mathrm{p}<0.001)$ when compared to the non-risk TCG/TCG configuration, esp. due to lower proportion of (n-6) PUFAs. These results remained significant even after adjustments for age and BMI $(\mathrm{p}=<0.001$, power $=0.98)$ or HOMA R $(p=<0.001$, power $=0.97)$. On the contrary, percentage of fasting MUFAs were significantly increased in women carrying the CTT haplotype in comparison with TCG/TCG homozygotes $(p=0.02$, power=0.66), see Fig. 4 .

\section{TCF7L2 risk haplotype CTT oGTT women - C-peptide}

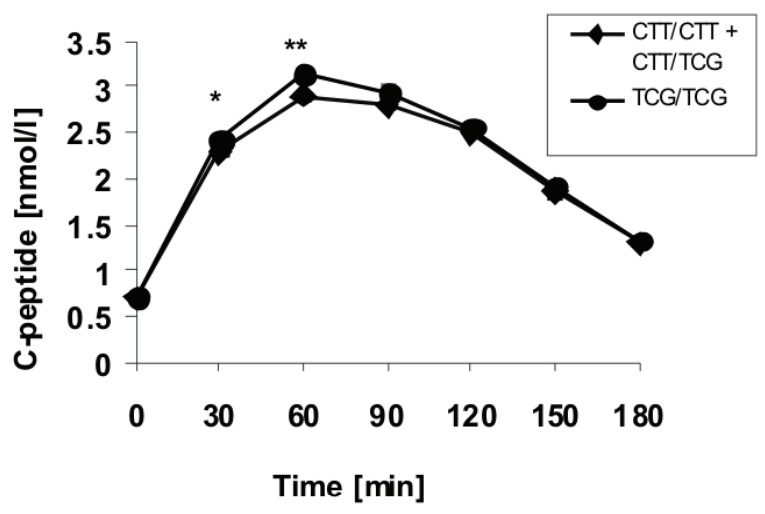

TCF7L2 haplotypes

AUC C-peptide

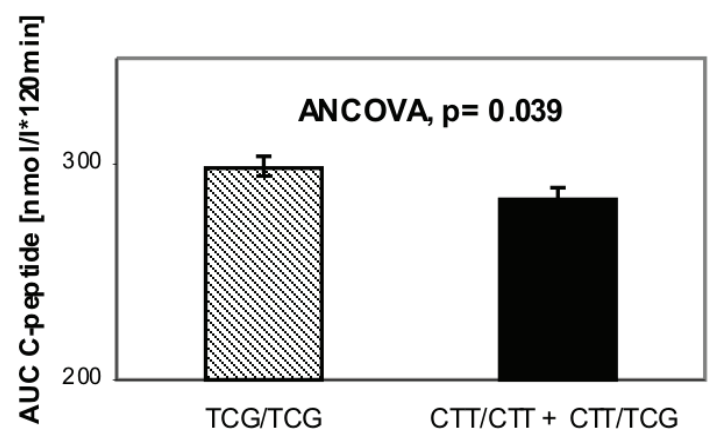

\section{TCF7L2 risk haplotype CTT} oGTT women - insulin

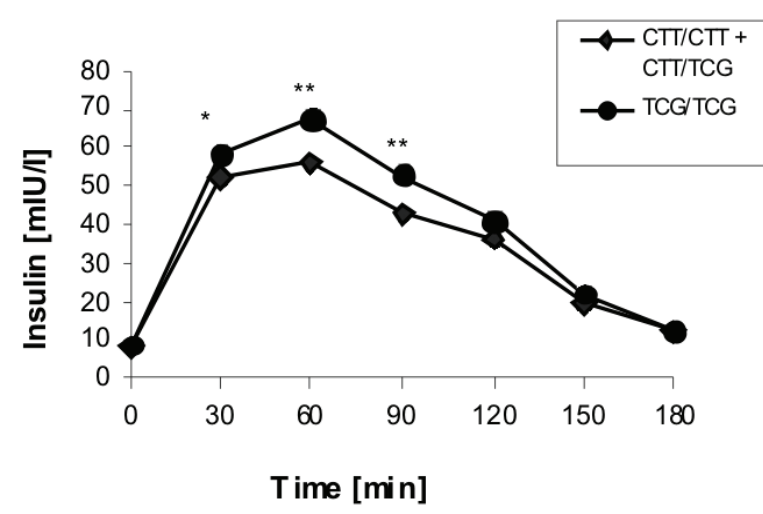

TCF7L2 haplotypes AUC IRI

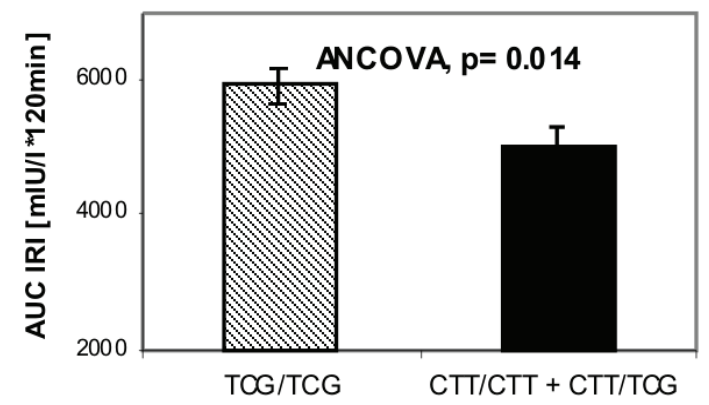

Fig. 1. The influence of risk haplotype CTT of the TCF7L2 gene on oGTT stimulated C-peptide and insulin in women. (AUC - area under the oGTT curve) 

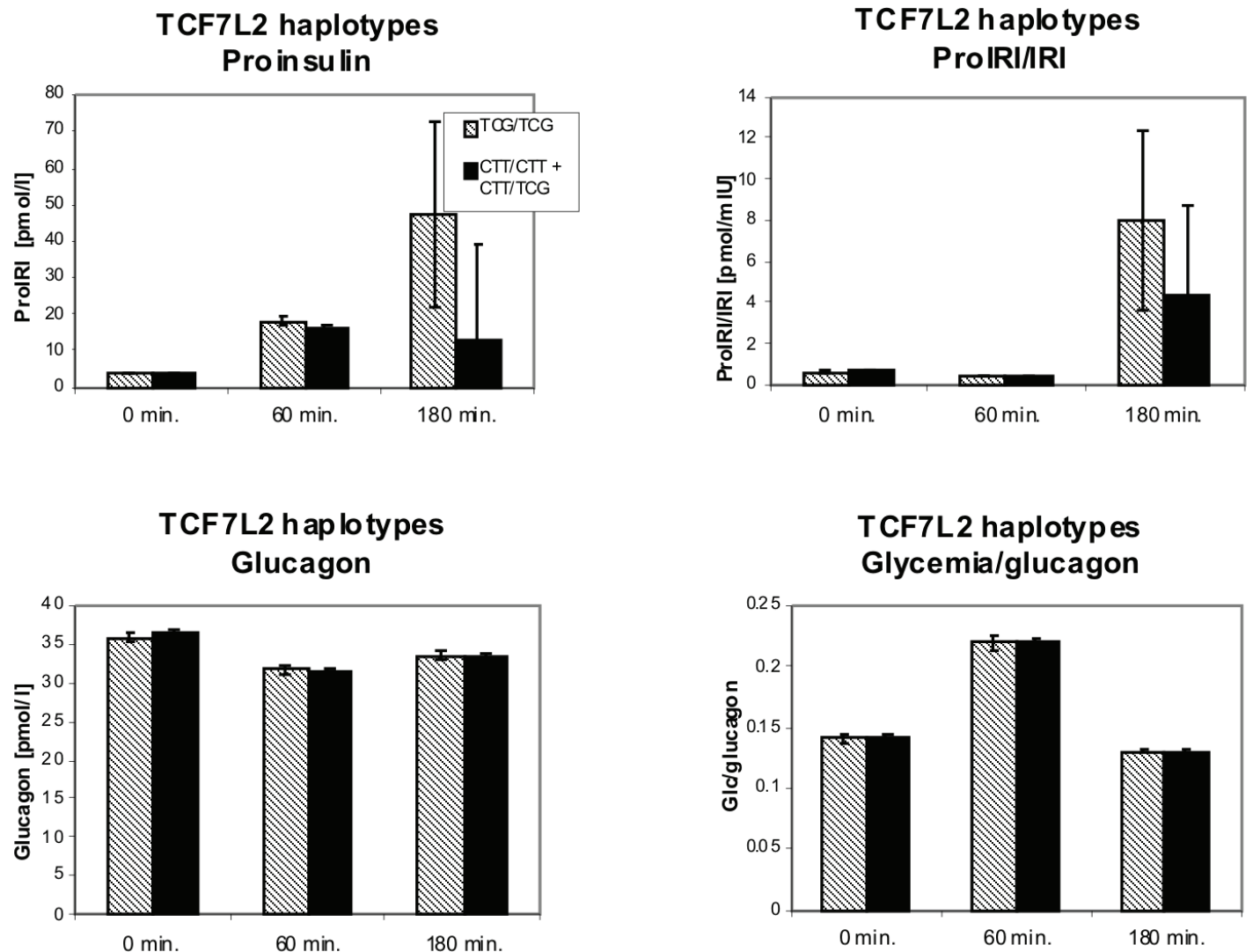

Fig. 2. The influence of risk haplotype $C T T$ of the $T C F 7 L 2$ gene on fasting and oGTT stimulated proinsulin levels, proinsulin/insulin ratio, glucagon level and glucose/glucagon ratio in women. (ProIRI - proinsulin, IRI - immunoreactive insulin)

TCF7L2 haplotypes HOMAF

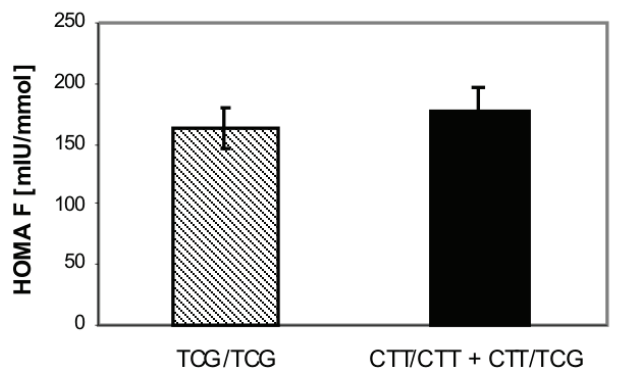

TCF7L2 haplotypes HOMAR

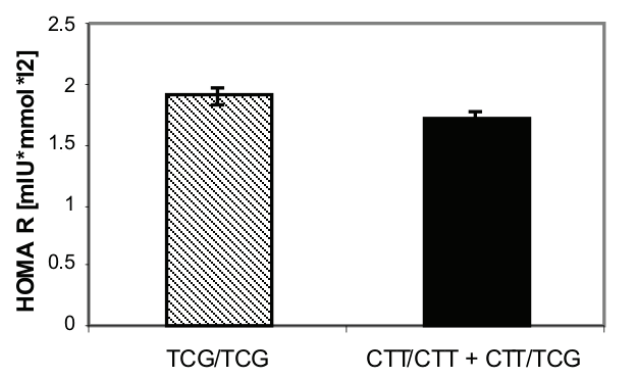

TCF7L haplotypes Insulinogenic index

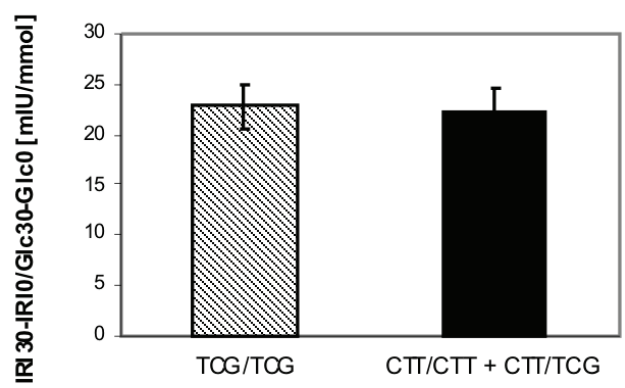

TCF7L2 haplotypes Matsuda index

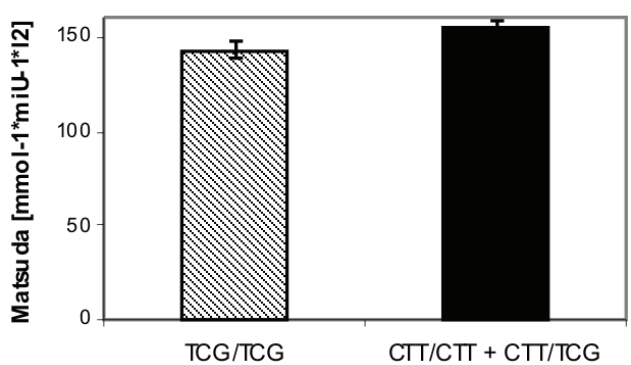

Fig. 3. The influence of risk haplotype CTT of the TCFZL2 gene on insulin secretion and insulin sensitivity: fasting and oGTT derived indices in women. 


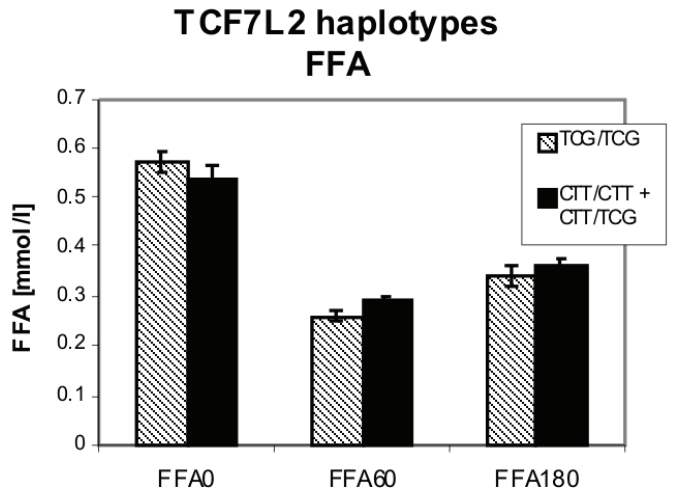

TCF7L2 haplotypes \%PUFA

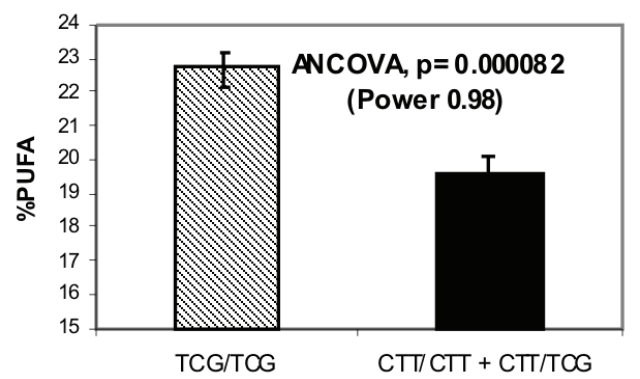

TCF7L2 haplotypes \%MUFA

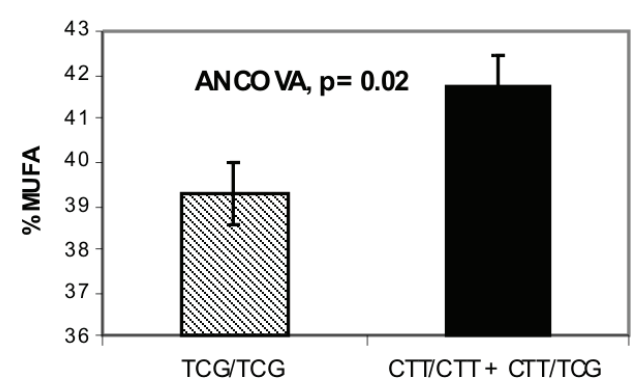

TCF7L2 haplotypes 18:2(n-6)

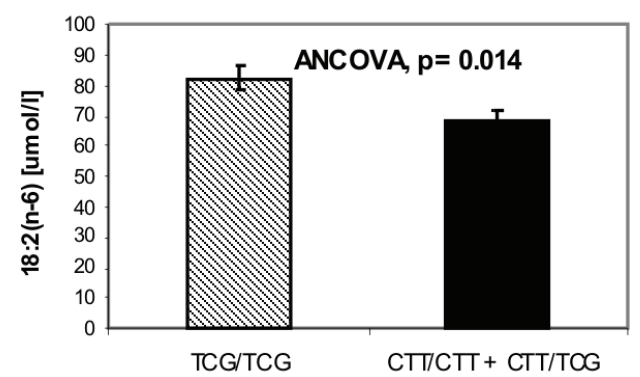

Fig. 4. The influence of risk haplotype CTT of the TCF7L2 gene on fasting and oGTT stimulated free fatty acid levels, \% of monounsaturated and polyunsaturated fatty acids and linoleic acid in women, data adjusted for age and BMI. (FFA - free fatty acids, $\%$ MUFA - \% monounsaturated FFA, \% PUFA - \% polyunsaturated FFA, 18:2(n-6) - linoleic acid)

\section{Discussion}

Our study performed on large cohorts of the Czech type 2 diabetics, offspring of diabetic parent(s), gestational diabetics, women with PCOS, and healthy controls without family history of these disorders confirmed the association of T2D with the TCF7L2 risk alleles rs7901695 (C), rs7903146 (T) and rs12255372 (T). The allele and genotype distribution of the TCF7L2 variants in the Czech T2D patients and controls as well as the ORs associated with the risk alleles conforms to the published data from other European cohorts reviewed by Tong et al. (2009). In the Czech representatives, risk of T2D associated with the homozygous risk haplotype configuration was higher compared to the risk associated with the homozygous status of the particular risk alleles evaluated separately. The highest OR for T2D was found for the CTT haplotype, which was also associated with decreased oGTT-stimulated insulin and C-peptide levels in non-diabetic women.

There are three novel findings in this study: 1) According to allele frequencies, the association of the tested risk alleles was stronger with T2D than with gestational diabetes. Surprisingly, the CTG/TCG haplotype combination was present twice as frequent in gestational diabetics compared with other cohorts and was associated with 2.6 fold increased risk of gestational diabetes. There are several published studies describing the association of TCF7L2 as well as other T2D susceptibility variants with increased risk of gestational diabetes mellitus (Shaat et al. 2007, Lauenborg et al. 2009, Pappa et al. 2010) which supports the hypothesis that gestational diabetes and T2D are two sides of the same entity. 2) In our study, PCOS was not associated with TCF $7 L 2$ variants. Our findings are supported by Barber et al. (2007) who did not find any association between rs7903146 and rs12255372 and PCOS in subjects of British/Irish and Finnish origin as well as no association with androgen levels. Similarly, large study performed on PCOS women of European ancestry did not find any association between 56 SNPs mapping to TCF7L2 and PCOS (Biyasheva et al. 2009). 3) The most exciting finding of this study was the association of the risk CTT haplotype with the fasting polyunsaturated and monounsaturated fatty acids. The non-diabetic female carriers of the CTT haplotype showed significantly 
decreased \% of PUFAs and increased \% of MUFAs in comparison with the non-risk TCG/TCG configuration in spite of the similar total fasting free fatty acids levels. The impact of the different diet of CTT carriers and noncarriers is not probable so it seems that the TCF7L2 influences the fate of FFAs in the organism. As the various types of FFAs have different effects on glucose level control, insulin sensitivity, insulin secretion and other metabolic pathways (De Santa et al. 2009), they could reciprocally influence the metabolic effect of the TCF7L2 genotype per se. The association of TCF7L2 variants with lipids independently of BMI (increased cholesterol and LDL-cholesterol levels in risk alleles carriers) was described for the first time by Sanhhera et al. (2008) in Indian population. Rs7903146 and rs12255372 were also associated with high triglyceride levels in Mexican and Finnish families with familial combined hyperlipidemia (Huertas-Vazquez et al. 2008). Warodomwichit et al. (2009) investigated the effect of TCF7L2 variants on postprandial lipemia and other metabolic syndrome-related traits and their modulation by dietary fat. The authors identified significant interactions between rs7903146 $\mathrm{T}$ allele variant and PUFAs intake modulating fasting VLDL particle concentrations and postprandial triglycerides, chylomicrons, total VLDL and large VLDL concentrations. These unfavorable atherogenic interactions of $\mathrm{T}$ allele carriership with PUFAs were exclusively due to high proportion of (n-6) PUFA intake. Also recent study (Perez-Martinez et al. 2010) links the TCF7L2 variants to the modulation of the postprandial lipid metabolism. Nevertheless, the atherosclerotic risk in communities (ARIC) study, in spite of dietary influences, did not find any association of TCF7L2 SNPs with incident coronary heart disease, ischemic stroke, cardiovascular disease, all-cause mortality, or prevalent peripheral artery disease (Bielinski et al. 2008). On the other hand, association of TCF7L2 rs11196224 with coagulation/inflammation was described recently in the LIPGENE cohort recruited from eight European countries (Delgado-Lista et al. 2011). In this study, there are also delineated remarkable interactions of TCF7L2 SNPs with fatty acids, suggesting extraordinary pleiotropic regulatory potential of the TCF 722 gene. Elevated SFAs modulated effects of rs11196224, rs7903146, rs176855538, rs290481 on insulin secretion (insulin level, AIRg), insulin resistance (HOMA-IR), coagulation (tPA), and inflammation (IL-6).

Our findings provide evidence of interaction between TCF7L2 variants and FFAs spectra and thus indicate involvement of the gene in lipid metabolism. However, further study is needed to elucidate the mechanisms by which TCF7L2 risk haplotype really influences the proportion of fasting PUFAs (esp. linoleic), MUFAs as well as SFAs and to investigate further consequences of the interactions between the genetic and the environmental factors.

\section{Conflict of Interest}

There is no conflict of interest.

\section{Acknowledgements}

We would like to thank all the subjects who participated in this study and to all our colleagues for excellent nurse and laboratory assistance. Supported by grant NS102093/2009 by the Ministry of Health of the Czech Republic.

\section{References}

BARBER TM, BENNETT AJ, GROVES CJ, SOVIO U, RUOKONEN A, MARTIKAINEN H, POUTA A, HARTIKAINEN AL, ELLIOTT P, WASS JA, JARVELIN MR, ZEGGINI E, FRANKS S, MCCARTHY MI: Disparate genetic influences on polycystic ovary syndrome (PCOS) and type 2 diabetes revealed by a lack of association between common variants within the TCF7L2 gene and PCOS. Diabetologia 50: 2318-2322, 2007.

BARRETT JC, FRY B, MALLER J, DALY MJ: Haploview: analysis and visualization of LD and haplotype maps. Bioinformatics 21: 263-265, 2005.

BIELINSKI SJ, PANKOW JS, FOLSOM AR, NORTH KE, BOERWINKLE E: TCF7L2 single nucleotide polymorphisms, cardiovascular disease and all-cause mortality: the Atherosclerosis Risk in Communities (ARIC) study. Diabetologia 51: 968-970, 2008.

BIYASHEVA A, LEGRO RS, DUNAIF A, URBANEK M: Evidence for association between polycystic ovary syndrome (PCOS) and TCF7L2 and glucose intolerance in women with PCOS and TCF7L2. J Clin Endocrinol Metab 94: 2617-2625, 2009. 
BLAHA P: ANTROPO - ein Programm fur automatische Bearbeitung anthopologischer Daten. Wiss Z Humboldt-Univ Berlin 5: 153-156, 1991.

CAUCHI S, FROGUEL P: TCF7L2 genetic defect and type 2 diabetes. Curr Diab Rep 8: 149-155, 2008.

CAUCHI S, MEYRE D, DINA C, CHOQUET H, SAMSON C, GALLINA S, BALKAU B, CHARPENTIER G, PATTOU F, STETSYUK V, SCHARFMANN R, STAELS B, FRUHBECK G, FROGUEL P: Transcription factor TCF7L2 genetic study in the French population: expression in human beta-cells and adipose tissue and strong association with type 2 diabetes. Diabetes 55: 2903-2908, 2006.

CHAUHAN G, SPURGEON CJ, TABASSUM R, BHASKAR S, KULKARNI SR, MAHAJAN A, CHAVALI S, KUMAR MV, PRAKASH S, DWIVEDI OP, GHOSH S, YAJNIK CS, TANDON N, BHARADWAJ D, CHANDAK GR: Impact of common variants of PPARG, KCNJ11, TCF7L2, SLC30A8, HHEX, CDKN2A, IGF2BP2, and CDKAL1 on the risk of type 2 diabetes in 5,164 Indians. Diabetes 59: 2068-2074, 2010.

CRUZ M, VALLADARES-SALGADO A, GARCIA-MENA J, ROSS K, EDWARDS M, ANGELES-MARTINEZ J, ORTEGA-CAMARILLO C, DE LA PENA JE, BURGUETE-GARCIA AI, WACHER-RODARTE N, AMBRIZ R, RIVERA R, D'ARTOTE AL, PERALTA J, PARRA EJ, KUMATE J: Candidate gene association study conditioning on individual ancestry in patients with type 2 diabetes and metabolic syndrome from Mexico City. Diabetes Metab Res Rev 26: 261-270, 2010.

De SILVA NM, STEELE A, SHIELDS B, KNIGHT B, PARNELl K, WEEDON MN, HATTERSLEY AT, FRAYLING TM: The transcription factor 7-like 2 (TCF7L2) gene is associated with Type 2 diabetes in UK community-based cases, but the risk allele frequency is reduced compared with UK cases selected for genetic studies. Diabet Med 24: 1067-1072, 2007.

DELGADO-LISTA J, PEREZ-MARTINEZ P, GARCÍA-RIOS A, PHILLIPS CM, WILLIAMS CM, GULSETH HL, HELAL O, BLAAK EE, KIEC-WILK B, BASU S, DREVON CA, DEFOORT C, SARIS WH, WYBRANSKA I, RISERUS U, LOVEGROVE JA, ROCHE HM, LOPEZ-MIRANDA J: Pleiotropic effects of TCF7L2 gene variants and its modulation in the metabolic syndrome: from the LIPGENE study. Atherosclerosis 214: 110-116, 2011.

EREQAT S, NASEREDDIN A, CAUCHI S, AZMI K, ABDEEN Z, AMIN R: Association of a common variant in TCF7L2 gene with type 2 diabetes mellitus in the Palestinian population. Acta Diabetol 47: 195-198, 2010.

ROTTERDAM ESHRE/ASRM-SPONSORED PCOS CONSENSUS WORKSHOP GROUP: Revised 2003 consensus on diagnostic criteria and long-term health risks related to polycystic ovary syndrome. Fertil Steril 81: 19-25, 2004.

FLOREZ JC, JABLONSKI KA, BAYLEY N, POLLIN TI, DE BAKKER PI, SHULDINER AR, KNOWLER WC, NATHAN DM, ALTSHULER D; DIABETES PREVENTION PROGRAM RESEARCH GROUP: TCF7L2 polymorphisms and progression to diabetes in the Diabetes Prevention Program. N Engl J Med 355: 241-250, 2006.

GAMBINO R, BO S, GENTILE L, MUSSO G, PAGANO G, CAVALLO-PERIN P, CASSADER M: Transcription factor 7-like 2 (TCF7L2) polymorphism and hyperglycemia in an adult Italian population-based cohort. Diabetes Care 33: 1233-1235, 2010.

GUSTAFSON B, SMITH U: WNT signalling is both an inducer and effector of glucagon-like peptide-1. Diabetologia 51: 1768-1770, 2008.

HUERTAS-VAZQUEZ A, PLAISIER C, WEISSGLAS-VOLKOV D, SINSHEIMER J, CANIZALES-QUINTEROS S, CRUZ-BAUTISTA I, NIKKOLA E, HERRERA-HERNANDEZ M, DAVILA-CERVANTES A, TUSIELUNA T, TASKINEN MR, AGUILAR-SALINAS C, PAJUKANTA P: TCF7L2 is associated with high serum triacylglycerol and differentially expressed in adipose tissue in families with familial combined hyperlipidaemia. Diabetologia 51: 62-69, 2008.

HUSEK P, SIMEK P, TVRZICKA E: Simple and rapid procedure for the determination of individual free fatty acids in serum. Anal Chim Acta 465: 433-439, 2002.

LAUENBORG J, GRARUP N, DAMM P, BORCH-JOHNSEN K, JORGENSEN T, PEDERSEN O, HANSEN T: Common type 2 diabetes risk gene variants associate with gestational diabetes. $J$ Clin Endocrinol Metab 94: $145-150,2009$. 
LEE SH, DEMETERCO C, GERON I, ABRAHAMSSON A, LEVINE F, ITKIN-ANSARI P: Islet specific Wnt activation in human type II diabetes. Exp Diabetes Res 2008: Article ID:728763, 2008.

LIN Y, LI P, CAI L, ZHANG B, TANG X, ZHANG X, LI Y, XIAN Y, YANG Y, WANG L, LU F, LIU X, RAO S, CHEN M, MA S, SHI Y, BAO M, WU J, YANG Y, YANG J, YANG Z: Association study of genetic variants in eight genes/loci with type 2 diabetes in a Han Chinese population. BMC Med Genet 11: 97, 2010.

LYSSENKO V, LUPI R, MARCHETTI P, DEL GUERRA S, ORHO-MELANDER M, ALMGREN P, SJOGREN M, LING C, ERIKSSON KF, LETHAGEN AL, MANCARELLA R, BERGLUND G, TUOMI T, NILSSON P, DEL PRATO S, GROOP L: Mechanisms by which common variants in the TCF7L2 gene increase risk of type 2 diabetes. J Clin Invest 117: 2155-2163, 2007.

MARTÍN DE SANTA OLALLA L, SÁNCHEZ MUNIZ FJ, VAQUERO MP: N-3 fatty acids in glucose metabolism and insulin sensitivity. Nutr Hosp 24: 113-127, 2009.

OSMARK P, HANSSON O, JONSSON A, RONN T, GROOP L, RENSTROM E: Unique splicing pattern of the TCF7L2 gene in human pancreatic islets. Diabetologia 52: 850-854, 2009.

PALMER ND, HESTER JM, AN SS, ADEYEMO A, ROTIMI C, LANGEFELD CD, FREEDMAN BI, NG MC, BOWDEN DW: Re-sequencing and analysis of variation in the TCF7L2 gene in African Americans suggests the SNP rs7903146 is the causal diabetes susceptibility variant. Diabetes 60: 662-668, 2010.

PAPADOPOULOU S, EDLUND H: Attenuated Wnt signaling perturbs pancreatic growth but not pancreatic function. Diabetes 54: 2844-2851, 2007.

PAPPA KI, GAZOULI M, ECONOMOU K, DASKALAKIS G, ANASTASIOU E, ANAGNOU NP, ANTSAKLIS A: Gestational diabetes mellitus shares polymorphisms of genes associated with insulin resistance and type 2 diabetes in the Greek population. Gynecol Endocrinol 27: 267-272, 2010.

PEARSON ER: Translating TCF7L2: from gene to function. Diabetologia 52: 1227-1230, 2009.

PEREZ-MARTINEZ P, DELGADO-LISTA J, PEREZ-JIMENEZ F, LOPEZ-MIRANDA J: Update on genetics of postprandial lipemia. Atheroscler Suppl 11: 39-43, 2010.

SANGHERA DK, NATH SK, ORTEGA L, GAMBARELLI M, KIM-HOWARD X, SINGH JR, RALHAN SK, WANDER GS, MEHRA NK, MULVIHILL JJ, KAMBOH MI: TCF7L2 polymorphisms are associated with type 2 diabetes in Khatri Sikhs from North India: genetic variation affects lipid levels. Ann Hum Genet 72: 499-509, 2008.

SHAAT N, LERNMARK A, KARLSSON E, IVARSSON S, PARIKH H, BERNTORP K, GROOP L: A variant in the transcription factor 7-like 2 (TCF7L2) gene is associated with an increased risk of gestational diabetes mellitus. Diabetologia 50: 972-979, 2007.

SMITH U: TCF7L2 and type 2 diabetes - we WNT to know. Diabetologia 50: 5-7, 2007.

STEPHENS M, DONNELLY P: A comparison of bayesian methods for haplotype reconstruction from population genotype data. Am J Hum Genet 73:1162-1169, 2003.

TONG Y, LIN Y, ZHANG Y, YANG J, ZHANG Y, LIU H, ZHANG B: Association between TCF7L2 gene polymorphisms and susceptibility to Type 2 Diabetes Mellitus: a large HuGE review and meta-analysis. BMC Med Genet 10: 10-15, 2009.

UNITED KINGDOM PROSPECTIVE DIABETES STUDY GROUP: Intensive blood glucose control with sulphonylureas or insulin compared with conventional treatment and risk of complications in patients with type 2 diabetes (UKPDS 33). Lancet 352: 837-853, 1998.

VILLAREAL DT, ROBERTSON H, BELL GI, PATTERSON BW, TRAN H, WICE B, POLONSKY KS: TCF7L2 variant rs7903146 affects the risk of type 2 diabetes by modulating incretin action. Diabetes 59: 479-485, 2010.

WARODOMWICHIT D, ARNETT DK, KABAGAMBE EK, TSAI MY, HIXSON JE, STRAKA RJ, PROVINCE M, AN P, LAI CQ, BORECKI I, ORDOVAS JM: Polyunsaturated fatty acids modulate the effect of TCF7L2 gene variants on postprandial lipemia. $J$ Nutr 139: 439-446, 2009.

WEN J, RONN T, OLSSON A, YANG Z, LU B, DU Y, GROOP L, LING C, HU R: Investigation of type 2 diabetes risk alleles support CDKN2A/B, CDKAL1, and TCF7L2 as susceptibility genes in a Han Chinese cohort. PLoS One 5: e9153, 2010. 
WORLD HEALTH ORGANIZATION EXPERT COMMITTEE: Definition, diagnosis and classification of diabetes mellitus and its complications. Report of a WHO Consultation, Part 1: Diagnosis and Classification of Diabetes Mellitus. World Health Organization, Geneva, 1999.

YAN Y, NORTH KE, BALLANTYNE CM, BRANCATI FL, CHAMBLESS LE, FRANCESCHINI N, HEISS G, KOTTGEN A, PANKOW JS, SELVIN E, WEST SL, BOERWINKLE E: Transcription factor 7-like 2 (TCF7L2) polymorphism and context-specific risk of type 2 diabetes in African American and Caucasian adults: the Atherosclerosis Risk in Communities study. Diabetes 58: 285-289, 2009.

ZEGGINI E, MCCARTHY MI: TCF7L2: the biggest story in diabetes genetics since HLA? Diabetologia 50: 1-4, 2007. 